\title{
CBS wt Allele
}

National Cancer Institute

\section{Source}

National Cancer Institute. CBS wt Allele. NCI Thesaurus. Code C129050.

Human CBS wild-type allele is located in the vicinity of $21 \mathrm{q} 22.3$ and is approximately 24 $\mathrm{kb}$ in length. This allele, which encodes cystathionine beta-synthase protein, is involved in the detoxification of homocysteine and the synthesis of cysteine. Mutation of the gene is associated with cystathionine beta-synthase deficiency (CBSD), which can lead to homocystinuria and an increase risk of thrombosis. 